\title{
Testicular Torsion in Neonate: A Rare Pathology
}

Fairouz Ayari*, Takoua Bensmail, Essid Latifa, Wiem Barbaria and Samia Kacem

Neonatology Intensive Care Unit of the Maternity and Neonatology Center, Tunis, Tunisia

\begin{abstract}
A case of neonatal testicular torsion is reported. The clinical course showed the appearance of enlarged testes and swollen and purplish penis in 6th hour of life. Surgical exploration revealed a bilateral extraravaginal testicular torsion which is a very rare entity.
\end{abstract}

Keywords: Testicular torsion; Physiological serum; Ultrasonography

\section{Introduction}

Neonatal testicular torsion also known as perinatal testicular torsion (PTT) is a rare event with controversies regarding its etiology, presentation, surgical management and sequelae. Although the cause is unknown, testicular torsion in the neonate is associated with fullterm birth, vaginal delivery, breech presentation, and birth trauma [1]. It was first described in 1897 by Taylor but the first bilateral cases were not reported until 1967 by Frederick et al. [2]. We describe a case of extravaginal bilateral and synchronous testicular torsion diagnosed within a few hours of birth.

\section{Case Report}

Houssayn is a male neonate born at 40 weeks 4 days of gestation via spontaneous vaginal delivery with a breech presentation to a healthy woman (para III). Pregnancy had been normal. The father hadn't associated medical conditions. Routine prenatal ultrasonograms had been normal. At birth the neonate weighed $3900 \mathrm{~g}$, and Apgar scores were 9 and 10. Physical examination, in $6^{\text {th }}$ hour of life, demonstrated that both testes were enlarged and purplish, a swollen and purplish penis as well as urethral bleeding. Ultrasonography did not show any defect. Immediate surgical exploration revealed a bilateral extraravaginal testicular torsion, both testicles are bluish, they recovered partially after untwisting and warming with physiological serum. The decision was to maintain them. Currently there was not enough longitudinal followup. A follow-up is scheduled for our patient in a pediatric surgery department.

\section{Discussion}

Perinatal testicular torsion (PTT) is an uncommon entity and represents about $12 \%$ of all testicular torsion during infancy [3]. Bilateral testicular torsion (BTT) is a rare neonatal situation. It is difficult to estimate its incidence exactly, since in the literature, the majority of authors have published isolated cases [4]. Baglaj and Carachi reported a series of 58 newborns with testicular torsion seen during a two decades period at a single institution and they have noted a frequency of $5.2 \%$ of BTT during the study period [4].

\section{PTT is divided into 2 groups: (1) prenatal}

Baglaj and Carachi reported a series of 58 newborns with testicular torsion seen during a two decades period at a single institution and they have noted a frequency of $5.2 \%$ of BTT during the study period [4].

\section{In utero torsion presenting at birth and (2) postnatal (neona- tal) torsion}

Which takes place during the first 30 days of life [5]. Following this type of nomenclature, Das and singer have found that $72.4 \%$ of neonatal torsions were prenatal and $27.5 \%$ occurred in the postnatal period, with a small percentage $0.5 \%$ having difficulty establishing onset of presentation [5]. It was found in a review of the literature that bilateral neonatal testicular torsion is extravaginal $92 \%$ of the time and was intravaginal only $8 \%$ [6-9]. Baglaj and Carachi were in agreement with these latest publications since all 58 boys had extravaginal torsion [4]. This is explained by the loose attachments of the tunica to the scrotal wall which occurs after birth [9]. BTT is generally extravaginal and synchronous in 50 to $80 \%$ of cases, and asynchronous bilateral cases are less frequent $[6,10]$. On the contrary, Baglaj and Carachi have documented an incidence of $33 \%$ of the latter form which is not negligible [4]. In the same review, it was found that torsion of the left testis occurs later than on the right side [4]. But in larger series no side preponderance can be detected [6]. In contrast to postnatal torsion, the prenatal torsion in the newborn mostly is insidious and asymptomatic. In the first case, the symptomatology is local and there are no associated systemic symptoms, such as pain or pyrexia [5]. For that it is necessary that every male new born is examinated immediately after birth and in full and that every enlarged scrotum is transilluminated to differentiate between a hydrocele and a surgical emergency [11].

According to Moesgaard and Felding, the differential diagnoses include traumatic hematoma, strangulated inguinal hernia and infection. More seldom epididymitis, orchitis or torsion of the appendix testis is seen. Testicular tumors and ectopic spleen or adrenal are exceedingly rare [12]. Ultrasonography and Doppler Ultrasonography are the preoperative exploration of choice to evaluate pathological conditions in the testes [13]. But it should not delay surgery because its specificity and sensitivity are poor: In our case the ultrasonography was normal and in the series of Jensen only one out of five cases with preoperative ultrasonography conclusively showed testicular torsion [14]. Urgent scrotal exploration in cases of neonatal torsion remains a subject of debate [15]. Experimental animal models of testicular ischemia have shown loss of spermatogenesis at 4 to $6 \mathrm{~h}$ and that of hormonal function at 10 to $12 \mathrm{~h}$ after diminished testicular blood flow [16]. Based on these results some authors are of the

*Corresponding author: Feirouz Ayari, Neonatology Intensive Care Unit of the Maternity and Neonatology Center, Tunis, 1110, Tunisia, Tel: 0021692035624; Email: ayarifeirouz@yahoo.fr

Received May 11, 2017; Accepted February 09, 2018; Published February 16 2018

Citation: Ayari F, Bensmail T, Latifa E, Barbaria W, Kacem S (2018) Testicular Torsion in Neonate: A Rare Pathology. Health Care Current Reviews 6: 220. doi: 10.4172/2375-4273.1000220

Copyright: (C) 2018 Ayari F, et al. This is an open-access article distributed unde the terms of the Creative Commons Attribution License, which permits unrestricted use, distribution, and reproduction in any medium, provided the original author and source are credited. 
opinion that surgery should be postponed in case of prenatal testicular torsion (In utero) which are never salvageable [5,17]. Contrariwise Roth et al. have adopted the strategy of emergent surgical exploration in cases of prenatal torsion. So that the other testicle could be saved in case of bilateral asynchronous torsion [18]. In case of postnatal testicular torsion, it is unanimously agreed to operate in an emergency in the hope of saving what can be saved $[4,5,12,14,17]$. Urgent surgery is recommended in cases of postnatal torsion, but the chance of saving the testis remains poor $[14,18,19]$

\section{Conclusion}

Postnatal torsion is a surgical emergency and bilateral testicular torsion is associated with a poor prognosis. Therefore, the neonatologist should be careful and examine the neonate in full, thereby allowing rapid intervention and preservation of testicle.

\section{References}

1. Taylor MR (1897) A case of testicle strangulated at birth; castration; recovery. Brit Med J 1: 458.

2. Frederick PL, Dushku N, Eraklis A J (1967) Simultaneous bilateral torsion of the testes in a newborn infant. Arch Sure 94: 299.

3. Brereton RJ, Manley S (1980) Acute scrotal pathology in boys. Z Kinderchir 26: 343-357.

4. Baglaj M, Carachi R (2007) Neonatal bilateral testicular torsion: A Plea for emergency exploration. J Urol 177: 2296-2299.

5. Das S, Singer A (1990) Controversies of perinatal torsion of the spermatic cord: A review, survey and recommendations. J Urol 143: 231-233.

6. Burge DM (1987) Neonatal testicular torsion and infarction: Aetiology and management. Br J Urol 59: 70-73.
7. Lyon RP (1961) Torsion of the testicle in childhood: A painless emergency requiring controlateral orchiopexy. JAMA 178: 702

8. Lester DB, Gummess GH (1961) Torsion of the spermatic cord in the newborn infant. J Urol 86: 631

9. Jerkins GR, Noe HN, Hollabaugh RS (1983) Spermatic cord torsion in the neonate. J Urol 129: 121

10. LaQuaglia MP, Bauer SB, Eraklis A, Feins N, Mandell J (1987) Bilateral neonatal torsion J Urol 198: 1051-1054.

11. Kay R, Strong DW, Tank ES (1980) Bilateral spermatic cord torsion in the neonate. J Urol 123: 293.

12. Moesgaard J, Felding C (1991) Uni- and bilateral torsion of the testes two cases in the neonate; a report of two cases. Eur J Obstet \& Gynecol Reprod Biol 38: 239-242

13. Chmelnik M, Schenk JP (2010) Testicular torsion: Sonomorphological appearance as a predictor for testicular viability and outcome in neonates and children. Pediatr Surg Int 26: 281-286.

14. Jensen R, Ellebæk M, Rasmussen L, Qvist N (2015) Low success rate of salvage surgery for testicular torsion in newborns. Dan Med J 62: 4997.

15. Kaplan GW, Retik A, Snyder HM (2004) Neonatal torsion: immediate surgical exploration versus conservative management. Presented at the American Urologic Association, San Francisco, CA, USA.

16. Smith GI (1955) Cellular changes from graded testicular ischemia. J Urol 73 355-362.

17. Kaye JD, Levitt SB, Friedman SC (2008) Neonatal torsion: A 14-year experience and proposed algorithm for management. J Urol 179: 2377-2383.

18. Roth CC, Mingin GC, Ortenberg J (2011) Salvage of bilateral asynchronous perinatal testicular torsion. J Urol 185: 2464-2468.

19. Djahangirian O, Ouimet A, Saint-Vil D (2010) Timing and surgical management of neonatal testicular torsions. J Pediatr Surg 45: 1012-1015 